\section{NIH Director edged out}

\author{
by Colin Norman, Washington
}

For the second time in two years, the Director of the National Institutes of Health (NIH) has been fired, apparently because of disagreements with other key administration officials over how biomedical research should be managed and funded in the United States.

Last month, Dr Robert S. Stone, who had been NIH Director since May 1973, was asked to resign by Dr Charles C. Edwards, the top health official in the Department of Health, Education and Welfare (HEW). The event immediately evoked a chorus of protests from several prominent biomedical scientists who charged in a statement put out by the Federation of American Scientists that the NIH is being subjected to "unwarranted and counterproductive political control".

Although no official reasons have yet been given, Stone's downfall is widely believed to have resulted from his opposition to further cutbacks in the NIH's budget and also from his failure to see eye-to-eye with Edwards on the role that the NIH should play in the total national health care programme. In any case, the troubles between Stone and the top brass at HEW (of which the NIH is officially a part) are symptomatic of the widespread disquiet within the biomedical research community over the administration's policies for the NIH.

The disquiet stems chiefly from the

\section{University of Ghana celebrates jubilee}

DURING the week (November 30 to December 7) the University of Ghana, situated in the Accra suburb of Legon, held its silver jubilee celebrations. In true academic style, the university had arranged lectures and exhibitions as well as two graduation ceremonies-one for the normal crop of last year's graduates and one for the presentation of honorary degrees to distinguished luminaries, including Dr Conor Cruise O'Brien, former Vice-Chancellor of the university.

The silver jubilee celebrations at Legon, like the recent silver jubilee celebrations at the Nigerian University of Ibadan, are certainly justified, for both universities have played a vital role in producing the trained manpower needed to run a newly emergent state. Sometimes the training process has not run particularly smoothly. Legon's celebrations were actually to have been held fact that the autonomy which the NIH has traditionally enjoyed has been considerably eroded in the past few years. Until the late 1960s there was little scrutiny of the NIH's programmes either by congress or the rest of the administration, but in the past couple of years, there has been a move to exert considerable management control over the NIH from Edwards's office in HEW. In addition the budget for biomedical research has levelled off and there has been considerable redistribution of funds from several areas of research into the politically sensitive cancer programme.

But the chief bone of contention came early last year when the administration proposed to scrap the NIH's training and fellowship programmes. Dr Robert Q. Marston, Stone's predecessor as Director of the NIH, was in fact fired when he resisted that proposal. After that, the administration let it be known that it was considering some radical surgery on the NIH's peer review system. Although both those moves have since been thwarted, largely because of loud protestations from biomedical scientists, Stone's forced departure is being viewed as yet another move towards tighter political control over the NIH from bureaucrats in HEW.

In an unrelated move, Dr Edwards himself resigned from the government to take up a post in industry a week after Stone's resignation was made known. Two top health posts are therefore vacant and the biomedical research community is anxiously waiting to see who will fill them.

last March but student demonstrations led to a closure of all three Ghanaian universities and to the cancellation of the original silver jubilee celebrations for Legon. Dr Alex Kwapong, the University of Ghana's skilful ViceChancellor has managed to keep the situation quiet this academic year, however and the university's stock has risen appreciably since March. Kwapong is a masterful negotiator and diplomat whose leadership and individualistic style, based on the groundwork laid by his predecessors, have helped to secure international prestige and financial aid for the campus.

Although all Kwapong's subordinates may not have his flair for administration, there has been significant growth in the university. The University of Ghana Medical School, which simultaneously celebrated its tenth anniversary, recently started dental and postgraduate courses. In addition, various other programmes such as computer science, journalism and population dynamics have all been set up within the past two years.

The University has, in the past, been fortunate in attracting distinguished academics and promising young graduates to fill its teaching and research posts. This is, in part, a result of the generosity of the British, Canadian and Dutch governments who provide finance and high level manpower through technical assistance schemes. It is difficult to find Ghanaians of the appropriate calibre to man the nation's universities. The pecuniary rewards overseas, especially in the United States, are so enticing that Ghana, in common with all developing countries, suffers from a severe brain drain.

Overall the university academic staff is $75 \%$ Ghanaian but this proportion varies greatly from faculty to faculty.

In the scientific disciplines, where $41 \%$ of the professors and lecturers are non-Ghanaians, the loss of promising Ghanaians is most acute. Their absence abroad is most unfortunate, since the high quality of Legon's scientific research was documented in a recent study of the faculty of science funded by the Ford Foundation. The Ford Foundation's report also suggested a vigorous infusion of money and equipment to maintain the existing high standards. Unfortunately, in the present bleak economic climate, no benefactor has as yet been found to fulfil the committee's recommendations.

In a shrewd display of foresight, the Ghanaian government launched "Operation Feed Yourself" in 1972 in an effort to achieve self-sufficiency in food production. The faculty of agriculture met this challenge by expanding its research programme to improve the varieties of tropical rice and sugar cane being grown in Ghana. As a peripheral benefit the expanded production on the research farms has helped both the university, which can now economise by feeding its students some homegrown agricultural produce, and the Legon housewife, who can now buy hitherto unobtainable goods such as pasteurised milk, frankfurters and liver sausage.

Contemplating Legon's success in the past twenty-five years leads to great hopes for the next twenty-five. It is no mean achievement to teach well and to carry out good quality research in a developing country subject to an acute shortage of foreign exchange delays in imports, low indigenous salaries, a rate of inflation of $20 \%$ and a lack of technical staff, and where the whole economic climate revolves around the vagaries of a single agricultural commodity-cocoa. The ability to surmount these obstacles speaks well for the dons at Legon who, in the words of the university's motto, have achieved "progress with integrity", 